\title{
Indikator Karakteristik Fisik Rumah Dominan dalam Penentuan Status Kemiskinan untuk Program Rehab Rumah tidak Layak Huni di Kabupaten Sidoarjo
}

\author{
Anita Diyanti Puteri, Hari Basuki Notobroto \\ Departemen Biostatistika dan Kependudukan \\ Fakultas Kesehatan Masyarakat Universitas Airlangga \\ Alamat Korespondensi: \\ Anita Diyanti Puteri, E-mail: Nitha.diyanti@yahoo.co.id
}

\begin{abstract}
Poverty is a problem in the construction of the Sidoarjo district. Sidoarjo regency government has conducted several policies in the poverty reduction process. Somethings that should be known by the government in poverty alleviation is the physical characteristics of homes in poor households in the Sidoarjo district. Physical characteristics of the house into one of the house into one of the measures in view of poverty and enable government in the process of poverty reduction policies. This study intended to determine dominant house physical characteristics indicator in poverty status for Unliveable House Rehabilitation Program located in Sidoarjo district. This study was observational with cross sectional design which cross sectional data was describing facts over a time period. The secondary data that being used was 99,492 household in Sidoarjo district from PPLS (2011). Data analyzed bivariabel, followed by multivariabel and logistic regression multinomial. The results showed that the significant variables poverty status is ownership status, roof type and quality, wall type and quality, and floor type. The dominant house physical characteristics indicator toward poverty status is floor type.
\end{abstract}

Keywords: poverty status, house physical characteristic indicator

\begin{abstract}
ABSTRAK
Kemiskinan menjadi masalah dalam pembangunan di Kabupaten Sidoarjo. Pemerintah Kabupaten Sidoarjo telah melakukan beberapa kebijakan dalam proses penanggulangan kemiskinan tersebut. Beberapa hal yang harus diketahui oleh pemerintah dalam penanggulangan kemiskinan adalah karakteristik fisik rumah pada rumah tangga miskin di Kabupaten Sidoarjo. Karakteristik fisik rumah menjadi salah satu ukuran dalam melihat kemiskinan dan mempermudah pemerintah dalam proses pembuatan kebijakan penanggulangan kemiskinan. Penelitian ini bertujuan untuk menentukan indikator karakteristik fisik rumah yang dominan dalam penentuan status kemiskinan untuk program rehab rumah tidak layak huni di Kabupaten Sidoarjo. Jenis penelitian yang digunakan dalam penelitian ini adalah observational karena hanya pengamatan terhadap data yang telah tersedia dan berbentuk cross sectional. Data cross sectional merupakan data yang menerangkan keadaan selama satu periode waktu. Penelitian ini menggunakan data sekunder yang peroleh dari hasil data PPLS tahun 2011 dengan unit analisis yaitu Kabupaten Sidoarjo yang terdiri dari 99.492 rumah tangga. Data dianalisis secara bivariabel, multivariabel dan dilanjutkan dengan regresi logistik multinomial. Hasil penelitian menunjukkan bahwa variabel yang signifikan terhadap status kemiskinan adalah status penguasaan bangunan, jenis atap terluas, kualitas atap, jenis dinding terluas, kualitas dinding dan jenis lantai. Indikator karakteristik fisik rumah yang berpengaruh paling dominan terhadap status kemiskinan yaitu jenis lantai.
\end{abstract}

Kata kunci: status kemiskinan, indikator karakteristik fisik rumah

\section{PENDAHULUAN}

Kemiskinan merupakan salah satu ukuran terpenting untuk mengetahui tingkat kesejahteraan suatu rumah tangga. Status kemiskinan di suatu wilayah digunakan untuk mengukur tingkat kesejahteraan di wilayah tersebut. Masalah kemiskinan menjadi salah satu tema utama pembangunan. Keberhasilan dan kegagalan pembangunan dapat diukur berdasarkan perubahan pada status kemiskinan (Suryahadi dan Sumarto, 2001).

Rumah sebagai kebutuhan dasar mempunyai sifat yang berbeda dari kebutuhan lainnya. diperlukan penanganan dengan perencanaan 
yang seksama disertai keikutsertaan dan daya dukung dalam masyarakat. Pada dasarnya rumah merupakan tanggung jawab dari masyarakat itu sendiri. Menurut Sudjana (1996), rumah sebagai tempat tinggal beserta fasilitasnya harus memenuhi syarat-syarat yang layak untuk mendukung kehidupan dalam rangka pembangunan dari pribadi, keluarga, masyarakat, bangsa dan negara.

Pada kenyataannya untuk dapat mewujudkan rumah yang memenuhi syarat tersebut bukanlah hal yang mudah. Ketidakberdayaan dalam memenuhi kebutuhan rumah yang layak huni berbanding lurus dengan pendapatan dan pengetahuan tentang fungsi rumah itu sendiri. Pemberdayaan masyarakat miskin juga mencakup upaya program bantuan rumah tidak layak huni, demikian juga persoalan sarana prasarana lingkungan yang kurang memadai dapat menghambat tercapainya kesejahteraan suatu komunitas. Lingkungan yang kumuh atau sarana prasarana lingkungan yang minim dapat menyebabkan masalah sosial dan kesehatan.

Rumah tidak layak huni merupakan suatu hunian atau tempat tinggal yang tidak layak huni karena tidak memenuhi persyaratan untuk hunian baik secara teknis maupun non teknis. Pada umumnya rumah tak layak huni ini erat kaitannya dengan pemukiman kumuh.

Tumanggor (2007), menyatakan bahwa rumah yang layak yaitu pertanda terpenuhinya kesejahteraan masyarakat. Kondisi rumah penduduk yang semakin baik dari tahun ke tahun merupakan pertanda adanya peningkatan sosial ekonomi penduduk. Keadaan sosial ekonomi tersebut adalah seperti tingkat pendidikan dan tingkat pendapatan. Tingkat pendidikan seseorang akan mempengaruhi persepsinya dalam mewujudkan pembangunan rumah yang lebih baik. Tingkat pendapatan seseorang akan berpengaruh terhadap pemenuhan kebutuhan rumah.

Menurut data Laporan Pelaksanaan Penanggulangan Kemiskinan Daerah (LP2KD) Kabupaten Sidoarjo tahun 2014 angka kemiskinan di Kabupaten Sidoarjo mulai tahun 2006 sampai tahun 2009 mengalami tren penurunan setiap tahunnya. Pada tahun 2010 sempat mengalami kenaikan sekitar 0,5\%. Selepas tahun 2010 perkembangan angka kemiskinan di Kabupaten
Sidoarjo mengalami penurunan setiap tahunnya hingga mencapai $6,4 \%$ pada tahun 2012. Pada tahun 2013 jumlah angka kemiskinan kembali mengalami kenaikan $0,27 \%$ menjadi $6,69 \%$.

Dalam menghadapi permasalahan kemiskinan tersebut, Pemerintah Kabupaten Sidoarjo telah berupaya memberikan perhatian cukup besar dalam mendukung upaya pemerintah untuk meningkatkan kesejahteraan masyarakat. Salah satunya melalui pembangunan lingkungan dan kualitas hunian guna mendukung pengembangan kegiatan usaha ekonomi masyarakat dan pemberdayaan sumber daya manusia dengan memperhatikan tatanan sosial masyarakat. Wujud nyata dari upaya tersebut adalah pemberian bantuan dana stimulasi bagi warga miskin di Kabupaten Sidoarjo melalui program Rehab Rumah Tidak Layak Huni.

Program Rehab Rumah Tidak layak Huni bersifat bantuan ekonomi kepada pemilik rumah untuk membiayai perbaikan rumahnya. Namun dana bantuan tersebut sebagai stimulan saja untuk meningkatkan kemampuan swadaya masyarakat miskin. Jumlah rumah tidak layak huni milik keluarga miskin yang memperoleh bantuan rehab pada tahun 2013 di Kabupaten Sidoarjo, sebanyak 62 unit rumah atau 96,97\%, dari target yang direncanakan sebanyak 64 unit rumah sesuai data PPLS.

Kemiskinan menjadi masalah dalam pembangunan di Kabupaten Sidoarjo. Pemerintah Kabupaten Sidoarjo telah melakukan beberapa kebijakan dalam proses penanggulangan kemiskinan tersebut. Beberapa hal yang harus diketahui oleh pemerintah dalam penanggulangan kemiskinan adalah karakteristik fisik rumah pada rumah tangga miskin di Kabupaten Sidoarjo. Karakteristik fisik rumah menjadi salah satu ukuran dalam melihat kemiskinan dan mempermudah pemerintah dalam proses pembuatan kebijakan penanggulangan kemiskinan.

Penduduk miskin biasanya dikaji dalam unit rumah tangga, bukan dalam unit individu. Kemiskinan juga dianalisis dalam unit rumah tangga. Ada beberapa alasan untuk menganalisis rumah tangga miskin daripada penduduk atau individu miskin. Pertama, kemiskinan pada hakikatnya merupakan cermin keadaan ekonomi rumah tangga. Kedua, apabila ditemukan data 
rumah tangga miskin maka intervensi terhadap rumah tangga akan lebih efektif dibandingkan dengan intervensi kemiskinan terhadap individu yang cenderung mengarah pada pandangan bahwa orang miskin memiliki karakteristik sebagai penyebab kemiskinannya.

Kategori status rumah tangga miskin menjadi tiga terdiri dari Rumah Tangga Sangat Miskin (RTSM), Rumah Tangga Miskin (RTM), dan Rumah Tangga Hampir Miskin (RTHM).

Tujuan penelitian ini adalah untuk menentukan indikator karakteristik fisik rumah yang lebih dominan dalam penentuan status kemiskinan untuk program rehab rumah tidak layak huni di Kabupaten Sidoarjo.

\section{METODE PENELITIAN}

Jenis penelitian yang digunakan dalam penelitian ini adalah observational karena hanya pengamatan terhadap data yang telah tersedia. Data cross sectional merupakan data yang menerangkan keadaan selama satu periode waktu.

Data yang digunakan dalam penelitian ini adalah data sekunder yang diambil dari hasil pendataan Program Perlindungan Sosial (PPLS) tahun 2011. Data tersebut meliputi data Rumah Tangga Sasaran (RTS) yang didalamnya terdiri dari tiga kelompok yaitu sangat miskin, miskin dan hampir miskin. Data indikator karakteristik fisik rumah meliputi status penguasaan bangunan tempat tinggal, jenis atap terluas, kualitas atap, jenis dinding terluas, kualitas dinding dan jenis lantai. Unit analisis yaitu 99.492 rumah tangga di Kabupaten Sidoarjo.

Data yang telah terkumpul akan diklasifikasikan menurut kategori serta dilakukan pengolahan data statistik menggunakan bantuan komputer yaitu SPSS. Data dianalisis secara deskriptif analitik. Secara deskriptif dengan menggunakan tabulasi silang, sedangkan secara analitik dengan bantuan program komputer menggunakan regresi logistik multinomial.

Data dianalisis secara bivariabel dan multivariabel. Analisis regresi logistik digunakan untuk melihat pengaruh antara variabel independen terhadap variabel dependen yang berupa kategorik dan untuk memprediksi nilai
Tabel 1. Variabel Penelitian

\begin{tabular}{|c|c|}
\hline Label & Kategori \\
\hline $\begin{array}{l}\text { Status Kemiskinan } \\
\text { (Y) }\end{array}$ & $\begin{array}{ll}1 & =\text { Sangat miskin } \\
2 & =\text { Miskin } \\
3 & =\text { Hampir miskin }\end{array}$ \\
\hline $\begin{array}{l}\text { Status Penguasaan } \\
\text { Bangunan tempat } \\
\text { tinggal }\left(\mathrm{X}_{1}\right)\end{array}$ & $\begin{array}{ll}1 & =\text { Milik Sendiri } \\
2 & =\text { Kontrak } / \text { sewa } \\
3 & =\text { Lainnya }\end{array}$ \\
\hline $\begin{array}{l}\text { Jenis Atap Terluas } \\
\left(\mathrm{X}_{2}\right)\end{array}$ & $\begin{array}{ll}1 & =\text { Ijuk/Rumbai } \\
2 & =\text { Seng/Asbes } \\
3 & =\text { Sirap } \\
4 & =\text { Beton } \\
5 & =\text { Genteng } \\
6 & =\text { Lainnya }\end{array}$ \\
\hline Kualitas Atap $\left(\mathrm{X}_{3}\right)$ & $\begin{array}{ll}1 & =\text { Jelek/kualitas rendah } \\
2 & =\text { Bagus/kualitas tinggi } \\
3 & =\text { Lainnya }\end{array}$ \\
\hline $\begin{array}{l}\text { Jenis Dinding } \\
\text { Terluas }\left(\mathrm{X}_{4}\right)\end{array}$ & $\begin{array}{ll}1 & =\text { Bambu } \\
2 & =\text { Kayu } \\
3 & =\text { Tembok } \\
4 & =\text { Lainnya }\end{array}$ \\
\hline $\begin{array}{l}\text { Kualitas Dinding } \\
\left(\mathrm{X}_{5}\right)\end{array}$ & $\begin{array}{ll}1 & =\text { Jelek/kualitas rendah } \\
2 & =\text { Bagus/kualitas tinggi } \\
3 & =\text { Lainnya }\end{array}$ \\
\hline Jenis lantai $\left(\mathrm{X}_{6}\right)$ & $\begin{array}{ll}1 & =\text { Bambu } \\
2 & =\text { Tanah } \\
3 & =\text { Bukan tanah/bambu }\end{array}$ \\
\hline
\end{tabular}

suatu variabel dependen berdasarkan nilai variabel independen (Uyanto, 2006).

Variabel penelitian yang digunakan dalam penelitian ini adalah pada Tabel 1 .

\section{HASIL PENELITIAN}

\section{Gambaran Umum Kabupaten Sidoarjo}

Kabupaten Sidoarjo dikenal dengan sebutan Kota Delta, karena berada di antara dua sungai besar pecahan Kali Brantas, yakni Kali Mas dan Kali Porong. Kabupaten Sidoarjo terbagi menjadi 18 Kecamatan, 322 desa dan 31 kelurahan.

\section{Karakteristik Unit Penelitian}

Karakteristik unit penelitian meliputi status kemiskinan, status penguasaan bangunan tempat tinggal, jenis atap terluas, kualitas atap, jenis dinding terluas, kualitas dinding dan jenis lantai. 


\section{Hasil Analisis Bivariabel}

Analisis bivariabel digunakan untuk mendapatkan gambaran tentang apakah ada pengaruh antara variabel independen dengan variabel dependen.

\section{Status Penguasaan Bangunan}

Tempat tinggal merupakan kebutuhan yang sangat mendasar bagi kehidupan setiap orang suatu rumah tangga. Dalam pemenuhan kebutuhan tersebut tidak semua orang dapat memenuhinya dengan mudah. Distribusi status kemiskinan berdasarkan status penguasaan bangunan dapat dilihat pada Tabel 2 .
Berdasarkan distribusi status penguasaan bangunan menunjukkan bahwa kategori sangat miskin lebih banyak dimiliki oleh rumah tangga dengan status penguasaan selain kontrak/ sewa dan milik sendiri $(36,7 \%)$ dibandingkan dengan rumah tangga yang status penguasaan milik sendiri $(28,0 \%)$. Kategori miskin lebih banyak dimiliki oleh rumah tangga yang status penguasaan bangunan milik sendiri (36,1\%).

Berdasarkan hasil analisis regresi logistik multinomial yaitu perbandingan antara kategori sangat miskin dan hampir miskin menunjukkan bahwa rumah yang memiliki status penguasaan bangunan kontrak/sewa, selain kontrak atau sewa dan milik sendiri cenderung mengalami risiko

Tabel 2. Distribusi Status Kemiskinan Berdasarkan Status Penguasaan Bangunan, Jenis Atap Terluas, Kualitas Atap, Jenis Dinding Terluas, Kualitas Dinding dan Jenis Lantai

\begin{tabular}{|c|c|c|c|c|c|c|c|c|}
\hline \multirow{3}{*}{ Variabel } & \multicolumn{6}{|c|}{$\begin{array}{l}\text { Status Kemiskinan } \\
\end{array}$} & \multirow{2}{*}{\multicolumn{2}{|c|}{ Jumlah }} \\
\hline & \multicolumn{2}{|c|}{ Sangat Miskin } & \multicolumn{2}{|c|}{ Miskin } & \multicolumn{2}{|c|}{ Hampir Miskin } & & \\
\hline & $\mathbf{n}$ & $\%$ & $\mathbf{n}$ & $\%$ & n & $\%$ & $\mathbf{n}$ & $\%$ \\
\hline \multicolumn{9}{|c|}{ Status Penguasaan Bangunan } \\
\hline Milik Sendiri & 23105 & 28,0 & 29814 & 36,1 & 29570 & 35,8 & 82489 & 100,0 \\
\hline Kontrak/Sewa & 5346 & 32,7 & 5393 & 33,0 & 5615 & 34,3 & 16354 & 100,0 \\
\hline Lainnya & 238 & 36,7 & 194 & 29,9 & 217 & 33,4 & 649 & 100,0 \\
\hline Jumlah & 28689 & 28,8 & 35401 & 35,6 & 35402 & 35,6 & 99492 & 100,0 \\
\hline \multicolumn{9}{|l|}{ Jenis Atap Terluas } \\
\hline Ijuk/Rumbai & 19 & 54,3 & 11 & 31,4 & 5 & 14,3 & 35 & 100,0 \\
\hline Seng/Asbes & 1612 & 32,0 & 1625 & 32,2 & 1803 & 35,8 & 5040 & 100,0 \\
\hline Sirap & 103 & 64,0 & 38 & 23,6 & 20 & 12,4 & 161 & 100,0 \\
\hline Beton & 187 & 18,6 & 351 & 35,0 & 465 & 46,4 & 1003 & 100,0 \\
\hline Genteng & 26657 & 28,6 & 33348 & 35,8 & 33096 & 35,5 & 93101 & 100,0 \\
\hline Lainnya & 111 & 73,0 & 28 & 18,4 & 13 & 8,6 & 152 & 100,0 \\
\hline Jumlah & 28689 & 28,8 & 35401 & 35,6 & 35402 & 35,6 & 99492 & 100,0 \\
\hline \multicolumn{9}{|l|}{ Kualitas Atap } \\
\hline Jelek/Kualitas Rendah & 26275 & 30,1 & 31265 & 35,8 & 29780 & 34,1 & 87320 & 100,0 \\
\hline Bagus/Kualitas Tinggi & 2291 & 19,1 & 4097 & 34,2 & 5607 & 46,7 & 11995 & 100,0 \\
\hline Jumlah & 28566 & 28,8 & 35362 & 35,6 & 35387 & 35,6 & 99315 & 100,0 \\
\hline \multicolumn{9}{|l|}{ Jenis Dinding Terluas } \\
\hline Bambu & $1880 \mathrm{w}$ & 63,4 & 764 & 25,8 & 320 & 10,8 & 2964 & 100,0 \\
\hline Kayu & 1821 & 47,5 & 1275 & 33,3 & 735 & 19,2 & 3831 & 100,0 \\
\hline Tembok & 24891 & 26,9 & 33286 & 36,0 & 34312 & 37,1 & 92849 & 100,0 \\
\hline Lainnya & 97 & 46,6 & 76 & 36,5 & 35 & 16,8 & 208 & 100,0 \\
\hline Jumlah & 28689 & 28,8 & 35401 & 35,6 & 35402 & 35,6 & 99492 & 100,0 \\
\hline \multicolumn{9}{|l|}{ Kualitas Dinding } \\
\hline Jelek/Kualitas Rendah & 23931 & 29,2 & 29573 & 36,1 & 28358 & 34,6 & 81862 & 100,0 \\
\hline Bagus/Kualitas Tinggi & 2781 & 19,2 & 4988 & 34,5 & 6689 & 46,3 & 14458 & 100,0 \\
\hline Jumlah & 26712 & 27,7 & 34561 & 35,9 & 35047 & 36,4 & 96320 & 100,0 \\
\hline \multicolumn{9}{|l|}{ Jenis Lantai } \\
\hline Bambu & 168 & 57,5 & 100 & 34,2 & 24 & 8,2 & 292 & 100,0 \\
\hline Tanah & 6820 & 55,4 & 3568 & 29,0 & 1925 & 15,6 & 12313 & 100,0 \\
\hline Bukan Tanah/Bambu & 21701 & 25,0 & 31733 & 36,5 & 33453 & 38,5 & 86887 & 100,0 \\
\hline Jumlah & 28689 & 28,8 & 35401 & 35,6 & 35402 & 35,6 & 99492 & 100,0 \\
\hline
\end{tabular}


untuk sangat miskin lebih besar dibandingkan dengan rumah yang memiliki status penguasaan milik sendiri dengan nilai $\mathrm{p}$ sebesar 0,000 $(p<0,05)$. Berarti bahwa status penguasaan bangunan berpengaruh signifikan terhadap status kemiskinan. Perbandingan antara kategori miskin dan hampir miskin dengan rumah yang memiliki status penguasaan bangunan kontrak/ sewa, selain kontrak/sewa dan milik sendiri cenderung mengalami risiko untuk miskin lebih kecil dibandingkan dengan rumah yang memiliki status penguasaan milik sendiri dengan nilai $\mathrm{p}$ sebesar 0,317 dan 0,225 ( $p>0,05)$. Berarti bahwa status penguasaan bangunan tidak berpengaruh signifikan terhadap status kemiskinan.

\section{Jenis Atap Terluas}

Atap adalah penutup bagian atas suatu bangunan sehingga rumah tangga yang mendiami di bawahnya terlindung dari terik matahari dan sebagainya. Pada umumnya jenis atap rumah terluas yang dipergunakan adalah genteng. Distribusi status kemiskinan berdasarkan jenis atap terluas dapat dilihat pada Tabel 2.

Berdasarkan distribusi jenis atap terluas menunjukkan bahwa kategori sangat miskin lebih banyak dimiliki oleh rumah tangga yang jenis atapnya selain ijuk atau rumbai, seng atau asbes, sirap, beton dan genteng $(73,0 \%)$ dibandingkan dengan rumah yang jenis atapnya genteng $(28,6 \%)$. Kategori miskin lebih banyak dimiliki oleh rumah tangga sasaran yang jenis atapnya genteng $(35,8 \%)$.

Berdasarkan hasil analisis regresi logistik multinomial yaitu perbandingan antara kategori sangat miskin dan hampir miskin menunjukkan bahwa rumah yang memiliki jenis atap ijuk atau rumbai, seng atau asbes, sirap, lainnya cenderung mengalami risiko untuk sangat miskin lebih besar dibandingkan rumah dengan jenis atap genteng. Rumah yang jenis atapnya beton cenderung mengalami risiko untuk sangat miskin lebih kecil dibandingkan rumah yang memiliki jenis atap genteng dengan nilai $p$ sebesar $0,000(p<0,05)$. Berarti bahwa jenis atap terluas berpengaruh signifikan terhadap status kemiskinan. Perbandingan antara kategori miskin dan hampir miskin menunjukkan bahwa rumah dengan jenis atap ijuk atau rumbai, sirap, lainnya cenderung mengalami risiko untuk miskin lebih besar dibandingkan rumah yang memiliki jenis atap genteng. Rumah yang memiliki jenis atap seng atau asbes dan beton cenderung mengalami risiko untuk miskin lebih kecil dibandingkan jenis atap genteng dengan nilai $\mathrm{p}$ sebesar $0,001(\mathrm{p}<0,05)$. Berarti bahwa jenis atap terluas berpengaruh signifikan terhadap status kemiskinan.

\section{Kualitas Atap}

Dilihat dari kualitas atap tempat tinggal rumah tangga di Kabupaten Sidoarjo terdiri dari kualitas jelek atau kualitas rendah dan kualitas bagus atau kualitas tinggi. Distribusi status kemiskinan berdasarkan kualitas atap dapat dilihat pada Tabel 2.

Berdasarkan distribusi kualitas atap menunjukkan bahwa kategori hampir miskin lebih banyak dimiliki oleh rumah tangga yang kualitas atap bagus atau kualitas tinggi $(35,8 \%)$ dibandingkan dengan kualitas atap jelek/kualitas rendah $(34,2 \%)$. Kategori miskin lebih banyak dimiliki oleh rumah tangga sasaran yang kualitas atapnya jelek atau kualitas rendah.

Berdasarkan hasil analisis regresi logistik multinomial yaitu perbandingan antara kelompok sangat miskin dan hampir miskin menunjukkan bahwa rumah yang memiliki kualitas atap jelek atau kualitas rendah cenderung mengalami risiko untuk sangat miskin lebih besar dibandingkan rumah yang memiliki kualitas atap bagus atau kualitas tinggi dengan nilai $\mathrm{p}$ sebesar $0,000(\mathrm{p}<$ 0,05 ). Berarti bahwa kualitas atap berpengaruh signifikan terhadap status kemiskinan. Perbandingan antara kategori miskin dan hampir miskin menunjukkan bahwa rumah dengan kualitas atap jelek atau kualitas rendah cenderung mengalami risiko untuk miskin lebih besar dibandingkan kualitas atap bagus atau kualitas tinggi dengan nilai $\mathrm{p}$ atap sebesar $0,000(\mathrm{p}<$ 0,05 ). Berarti bahwa kualitas atap berpengaruh signifikan terhadap status kemiskinan.

\section{Jenis Dinding Terluas}

Dinding adalah sisi luar atau batas dari suatu bangunan atau penyekat dengan bangunan fisik lainnya. Suatu rumah tangga dinyatakan miskin menurut BPS menggunakan jenis dinding selain tembok, yaitu menggunakan kayu, bambu atau lainnya. Distribusi status kemiskinan berdasarkan jenis dinding terluas dapat dilihat pada Tabel 2. 
Berdasarkan distribusi kualitas atap menunjukkan bahwa kategori sangat miskin lebih banyak dimiliki oleh rumah tangga yang jenis dindingnya bambu $(63,4 \%)$ dibandingkan rumah dengan jenis dindingnya tembok $(26,9 \%)$, sedangkan kategori hampir miskin lebih banyak dimiliki oleh rumah yang jenis dindingnya tembok $(36,0 \%)$.

Berdasarkan hasil analisis regresi logistik multinomial yaitu perbandingan antara kategori sangat miskin dan hampir miskin menunjukkan bahwa rumah yang memiliki jenis dinding bambu, kayu dan lainnya cenderung mengalami risiko untuk sangat miskin lebih besar dibandingkan jenis dinding tembok dengan nilai $\mathrm{p}$ sebesar $0,000(\mathrm{p}<0,05)$. Berarti bahwa jenis dinding terluas berpengaruh signifikan terhadap status kemiskinan. Perbandingan antara kategori miskin dan hampir miskin menunjukkan bahwa rumah dengan jenis dinding bambu, kayu dan lainnya cenderung mengalami risiko untuk miskin lebih besar dibandingkan jenis dinding tembok dengan nilai $p$ sebesar $0,000(p<0,05)$. Berarti bahwa jenis dinding terluas berpengaruh signifikan terhadap status kemiskinan.

\section{Kualitas Dinding}

Kondisi fisik bangunan merupakan komponen yang paling berpengaruh dalam kualitas rumah termasuk juga fasilitas yang dimilikinya. Komponen yang ada didalamnya dapat langsung diidentifikasi dengan melihat fisik bangunan rumah yang dihuni. Distribusi status kemiskinan berdasarkan kualitas dinding dapat dilihat pada Tabel 2.

Berdasarkan distribusi kualitas dinding menunjukkan bahwa kategori hampir miskin lebih banyak dimiliki oleh rumah dengan kualitas dinding bagus atau kualitas tinggi $(46,3 \%)$ dibandingkan dengan rumah yang memiliki kualitas dinding jelek atau kualitas rendah (34,6\%). Kategori miskin lebih banyak dimiliki oleh rumah dengan kualitas dinding jelek atau kualitas rendah $(36,1 \%)$.

Berdasarkan hasil analisis regresi logistik multinomial yaitu perbandingan antara kategori sangat miskin dan hampir miskin menunjukkan bahwa rumah yang memiliki kualitas dinding jelek atau kualitas rendah cenderung mengalami risiko untuk sangat miskin lebih besar dibandingkan kualitas dinding bagus atau kualitas tinggi dengan nilai $p$ sebesar $0,000(p<0,05)$. Berarti bahwa kualitas dinding berpengaruh signifikan terhadap status kemiskinan. Perbandingan antara kelompok miskin dan hampir miskin menunjukkan rumah dengan kualitas dinding jelek atau kualitas rendah cenderung mengalami risiko untuk miskin lebih besar dibandingkan rumah yang memiliki kualitas dinding bagus atau kualitas tinggi dengan nilai $\mathrm{p}$ atap sebesar 0,000 $(p<0,05)$. Berarti bahwa kualitas dinding berpengaruh signifikan terhadap status kemiskinan.

\section{Jenis Lantai}

Kondisi rumah dapat dilihat dari jenis lantai bangunan tempat tinggal. Penggunaan kayu, papan, bambu atau tanah sebagai lantai bangunan tempat tinggal menjadi indikator suatu rumah tangga dinyatakan miskin. Distribusi status kemiskinan berdasarkan jenis lantai dapat dilihat pada Tabel 2.

Berdasarkan distribusi kualitas dinding menunjukkan bahwa kategori sangat miskin lebih banyak dimiliki oleh rumah tangga yang memiliki jenis lantai bambu (57,5\%) dibandingkan dengan rumah yang jenis lantainya bukan tanah atau bambu $(25,0 \%)$. Kategori hampir miskin lebih banyak dimiliki oleh rumah yang jenis lantainya bukan tanah atau bambu $(38,5 \%)$.

Berdasarkan hasil analisis regresi logistik multinomial yaitu perbandingan antara kategori sangat miskin dan hampir miskin menunjukkan bahwa rumah yang memiliki jenis lantai bambu dan tanah cenderung mengalami risiko untuk sangat miskin lebih besar dibandingkan jenis lantai bukan tanah atau bambu dengan nilai $\mathrm{p}$ sebesar 0,000 ( $\mathrm{p}<0,05)$. Berarti bahwa jenis lantai berpengaruh signifikan terhadap status kemiskinan. perbandingan antara kelompok miskin dan hampir miskin menunjukkan bahwa rumah dengan jenis lantai bambu dan tanah cenderung mengalami risiko untuk miskin lebih besar dibandingkan jenis lantai bukan tanah/ bambu dengan nilai $\mathrm{p}$ sebesar $0,000(\mathrm{p}<0,05)$. Berarti bahwa jenis lantai berpengaruh signifikan terhadap status kemiskinan. 


\section{Hasil Analisis Multivariabel}

Analisis multivariabel dengan cara memasukkan variabel secara bersama-sama untuk memeriksa ada atau tidaknya pengaruh antara variabel tersebut. Tabel 3 menunjukkan:

\section{Status Penguasaan Bangunan}

Status penguasaan bangunan merupakan variabel yang berpengaruh secara signifikan. Hal ini dapat dilihat dari nilai signifikansinya berkisar antara 0,000-0,126 ( $\mathrm{p}<0,05)$. Perbandingan antara kategori sangat miskin dan miskin menunjukkan bahwa rumah dengan status penguasaan bangunan kontrak atau sewa cenderung mengalami risiko untuk sangat miskin lebih besar dibandingkan yang memiliki rumah milik sendiri. Perbandingan antara kelompok miskin dan hampir miskin menunjukkan bahwa rumah dengan status penguasaan bangunan kontrak atau sewa dan selain kontrak atau sewa dan milik sendiri cenderung mengalami risiko untuk miskin lebih kecil dibandingkan yang memiliki rumah milik sendiri.

\section{Jenis Atap Terluas}

Jenis atap terluas merupakan variabel yang berpengaruh secara signifikan. Hal ini dapat dilihat dari nilai signifikansinya berkisar antara $0,000-0,915(\mathrm{p}<0,05)$. Perbandingan antara kelompok sangat miskin dan hampir miskin menunjukkan bahwa rumah dengan jenis atap sirap dan selain sirap, seng atau asbes, beton cenderung mengalami risiko untuk sangat miskin lebih besar dibandingkan rumah dengan jenis atap genteng. Rumah yang jenis atapnya seng atau asbes dan beton cenderung mengalami risiko untuk sangat miskin lebih kecil dibandingkan rumah yang jenis atapnya genteng. Perbandingan antara kelompok miskin dan hampir miskin menunjukkan bahwa rumah dengan jenis atap sirap cenderung mengalami risiko untuk miskin lebih besar dibandingkan rumah dengan jenis atap genteng. Rumah jenis atap seng atau asbes, beton selain seng atau asbes, sirap, beton cenderung mengalami risiko miskin lebih kecil dibandingkan rumah dengan atap genteng.

\section{Kualitas Atap}

Kualitas atap merupakan variabel yang berpengaruh secara signifikan. Hal ini dapat dilihat dari nilai signifikansinya sebesar 0,000 $(\mathrm{p}<0,05)$. Perbandingan antara kelompok sangat miskin dan hampir miskin menunjukkan bahwa rumah dengan kualitas atap jelek atau kualitas rendah cenderung mengalami risiko untuk sangat miskin lebih besar dibandingkan yang memiliki rumah dengan kualitas atap bagus atau kualitas tinggi. Perbandingan antara kelompok miskin dan hampir miskin menunjukkan bahwa rumah dengan kualitas atap jelek atau kualitas rendah cenderung mengalami risiko untuk miskin lebih besar dibandingkan rumah dengan kualitas atap bagus atau kualitas tinggi.

\section{Jenis Dinding Terluas}

Jenis dinding terluas merupakan variabel yang berpengaruh secara signifikan. Hal ini dapat dilihat dari nilai signifikansinya sebesar 0,000 $(\mathrm{p}<0,05)$.

Perbandingan antara kategori sangat miskin, miskin dan hampir miskin menunjukkan bahwa rumah dengan jenis dinding kayu cenderung mengalami risiko untuk sangat miskin dan miskin lebih besar dibandingkan rumah dengan jenis dinding tembok.

\section{Kualitas Dinding}

Kualitas dinding merupakan variabel yang berpengaruh secara signifikan. Hal ini dapat dilihat dari nilai signifikansinya sebesar 0,000 $(\mathrm{p}<0,05)$. Perbandingan antara kategori sangat miskin, miskin dan hampir miskin menunjukkan bahwa rumah dengan kualitas dinding jelek atau kualitas rendah cenderung mengalami risiko untuk sangat miskin dan miskin lebih besar dibandingkan rumah yang memiliki kualitas dinding bagus atau kualitas tinggi.

\section{Jenis Lantai}

Jenis lantai merupakan variabel yang berpengaruh secara signifikan. Hal ini dapat dilihat dari nilai signifikansinya berkisar antara $0,000-0,003(\mathrm{p}<0,05)$. Perbandingan antara 
Tabel 3. Hasil analisis Regresi Logistik Mulitinomial secara Multivariabel Status Kemiskinan Berdasarkan Status Penguasaan Bangunan, Jenis Atap Terluas, Kualitas Atap, Jenis Dinding Terluas, Kualitas Dinding dan Jenis Lantai

\begin{tabular}{|c|c|c|c|c|}
\hline & & B & Wald & Sig. \\
\hline \multirow{18}{*}{$\begin{array}{l}\text { Sanga } \\
\text { Miskin }\end{array}$} & Intercept & $-1,138$ & 1782,169 & 0,000 \\
\hline & Status Penguasaan Bangunan $=$ Kontrak $/$ Sewa & 0,036 & 2,336 & 0,126 \\
\hline & Status Penguasaan Bangunan = Lainnya & $-0,207$ & 3,372 & 0,066 \\
\hline & Status Penguasaan Bangunan $=$ Milik Sendiri $($ Ref $)$ & $0^{\mathrm{b}}$ & . & \\
\hline & Jenis Atap Terluas $=$ Seng $/$ Asbes & $-0,180$ & 19,974 & 0,000 \\
\hline & Jenis Atap Terluas $=$ Sirap & 1,579 & 38,848 & 0,000 \\
\hline & Jenis Atap Terluas = Lainnya & 0,077 & 0,011 & 0,915 \\
\hline & Jenis Atap Terluas $=$ Beton & $-0,239$ & 7,381 & 0,007 \\
\hline & Jenis Atap Terluas $=$ Genteng $($ Ref $)$ & $0^{\mathrm{b}}$ & & \\
\hline & Kualitas Atap $=$ Jelek/Kualitas Rendah & 0,384 & 102,795 & 0,000 \\
\hline & Kualitas Atap = Bagus/Kualitas Tinggi $($ Ref $)$ & $0^{\mathrm{b}}$ & . & \\
\hline & Jenis Dinding $=$ Kayu & 0,991 & 459,433 & 0,000 \\
\hline & Jenis Dinding $=$ Tembok $($ Ref $)$ & $0^{\mathrm{b}}$ & . & \\
\hline & Kualitas Dinding $=$ Jelek/Kualitas Rendah & 0,374 & 117,075 & 0,000 \\
\hline & Kualitas Dinding $=$ Bagus $/$ Kualitas Tinggi $($ Ref $)$ & $0^{\mathrm{b}}$ & . & \\
\hline & Jenis Lantai $=$ Bambu & 1,091 & 15,308 & 0,000 \\
\hline & Jenis Lantai $=$ Tanah & 1,480 & 2650,389 & 0,000 \\
\hline & Jenis Lantai $=$ Bukan tanah/bambu $(R e f)$ & $0^{\mathrm{b}}$ & . & . \\
\hline \multirow{18}{*}{ Miskin } & Intercept & $-0,366$ & 284,276 & 0,000 \\
\hline & Status Penguasaan Bangunan $=$ Kontrak $/$ Sewa & $-0,089$ & 16,885 & 0,000 \\
\hline & Status Penguasaan Bangunan = Lainnya & $-0,266$ & 6,359 & 0,012 \\
\hline & Status Penguasaan Bangunan $=$ Milik Sendiri $($ Ref $)$ & $0^{\mathrm{b}}$ & . & . \\
\hline & Jenis Atap Terluas $=$ Seng/Asbes & $-0,143$ & 14,880 & 0,000 \\
\hline & Jenis Atap Terluas $=$ Sirap & 0,601 & 4,708 & 0,030 \\
\hline & Jenis Atap Terluas = Lainnya & $-20,801$ & . & \\
\hline & Jenis Atap Terluas $=$ Beton & $-0,111$ & 2,403 & 0,121 \\
\hline & Jenis Atap Terluas $=$ Genteng $($ Ref $)$ & $0^{\mathrm{b}}$ & . & . \\
\hline & Kualitas Atap $=$ Jelek/Kualitas Rendah & 0,187 & 33,419 & 0,000 \\
\hline & Kualitas Atap = Bagus/Kualitas Tinggi $($ Ref $)$ & $0^{\mathrm{b}}$ & . & \\
\hline & Jenis Dinding $=$ Kayu & 0,525 & 122,185 & 0,000 \\
\hline & Jenis Dinding $=$ Tembok $($ Ref $)$ & $0^{\mathrm{b}}$ & . & 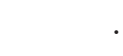 \\
\hline & Kualitas Dinding $=$ Jelek/Kualitas Rendah & 0,187 & 39,317 & 0,000 \\
\hline & Kualitas Dinding $=$ Bagus $/$ Kualitas Tinggi $($ Ref $)$ & $0^{\mathrm{b}}$ & . & . \\
\hline & Jenis Lantai $=$ Bambu & 0,833 & 8,880 & 0,003 \\
\hline & Jenis Lantai $=$ Tanah & 0,589 & 371,256 & 0,000 \\
\hline & Jenis Lantai $=$ Bukan tanah/bambu $($ Ref $)$ & $0^{\mathrm{b}}$ & . & \\
\hline
\end{tabular}


kelompok sangat miskin dan hampir miskin menunjukkan bahwa rumah dengan jenis lantai bambu dan tanah cenderung mengalami risiko untuk sangat miskin lebih besar dibandingkan yang memiliki rumah dengan jenis dinding bukan tanah atau bambu. Perbandingan antara kelompok miskin dan hampir miskin menunjukkan rumah dengan jenis lantai bambu dan tanah cenderung mengalami risiko untuk miskin lebih besar dibandingkan yang memiliki rumah dengan dinding bukan tanah bambu.

\section{PEMBAHASAN}

Penelitian ini menggunakan metode regresi logistik multinomial yang diterapkan pada status kemiskinan di Kabupaten Sidoarjo. Variabel yang diteliti yaitu jumlah rumah tangga sasaran dengan kategori sangat miskin, miskin dan hampir miskin pada tahun 2011 sebagai variabel respons. Variabel prediktor yaitu status penguasaan bangunan, jenis atap terluas, kualitas atap, jenis dinding terluas, kualitas dinding dan jenis lantai.

Data yang digunakan sebanyak 99.492 data rumah tangga sasaran tahun 2011. Data tersebut terdapat $28,8 \%$ status kemiskinan dengan kategori sangat miskin, 35,6\% dengan kategori miskin dan 35,6\% dengan kategori hampir miskin.

Rumah tidak layak huni tersebut ditunjukkan dengan kondisi jenis atap, dinding dan lantai. Jenis atap digunakan indikator beton, genteng, sirap, seng atau asbes, ijuk atau rumbai dan lainnya. Jenis dinding digunakan indikator tembok, kayu, bambu dan lainnya, sedangkan jenis lantai digunakan indikator bambu dan tanah. Disisi lain dari jenis atap, dinding dan lantai tersebut masih bisa dilihat kualitas atap, dinding dan lantai.

Hasil penelitian ini memperlihatkan bahwa 99.492 rumah tangga sasaran sebanyak 82489 rumah tangga $(81,71 \%)$ yang memiliki rumah sendiri atau milik sendiri sedangkan rumah tangga yang memiliki rumah kontrak/sewa sebanyak 16354 rumah tangga (17,53\%). Hal ini menunjukkan bahwa sebagian besar rumah

tangga sasaran memiliki rumah sendiri atau milik sendiri. Pada umumnya rumah milik sendiri ini berasal dari rumah warisan atau hibah dari orang tua baik orang tua kandung maupun mertua.
Adapun variabel jenis atap terluas menunjukkan bahwa 99.492 rumah tangga sasaran sebanyak 93101 rumah tangga $(92,31 \%)$ yang memiliki rumah dengan jenis atap genteng sedangkan rumah tangga yang memiliki rumah dengan jenis atap seng atau asbes sebanyak 5040 rumah tangga $(5,97 \%)$. Hal ini menunjukkan bahwa sebagian besar rumah tangga sasaran di Kabupaten Sidoarjo menggunakan jenis atap genteng.

Variabel kualitas atap tempat tinggal rumah tangga di Kabupaten Sidoarjo yang memiliki kualitas jelek atau kualitas rendah sebanyak 87320 rumah tangga $(88,23 \%)$ sedangkan yang memiliki kualitas bagus atau kualitas tinggi sebanyak 11995 rumah tangga (11,59\%).

Sesuai dengan kebijakan BPMPKB yang menyatakan bahwa kualitas jelek dan kualitas baik pada rumah tidak layak huni tidak terlalu berpengaruh dalam skala prioritas penyelesaian. Artinya yang kualitas baik dan jelek sama-sama harus segera dilakukan penyelesaian tetapi jika anggaran yang tersedia terbatas maka masih bisa dilakukan pada skala prioritas, di mana rumah tidak layak huni dengan kualitas jelek lebih diprioritaskan. Variabel kualitas dinding tempat tinggal rumah tangga di Kabupaten Sidoarjo yang memiliki kualitas jelek atau kualitas rendah sebanyak 81862 rumah tangga $(82,80 \%)$ sedangkan yang memiliki kualitas bagus atau kualitas tinggi sebanyak 14458 rumah tangga $(13,70 \%)$.

Karakteristik fisik rumah berdasarkan lantai rumahnya terbagi menjadi 3 kriteria yaitu bambu, tanah dan bukan tanah atau bambu. Mayoritas rumah tangga di Kabupaten Sidoarjo cenderung menggunakan bukan tanah atau bambu sebagai lantai bangunan tempat tinggal yaitu sebesar 86887 rumah tangga $(86,93 \%)$. Hal ini sesuai dengan Notoatmodjo (2003), yang menyatakan bahwa lantai yang baik adalah lantai yang keadaannya kering dan tidak lembab.

\section{SIMPULAN DAN SARAN}

\section{Simpulan}

Indikator Karakteristik Fisik Rumah Dalam Penentuan Status Kemiskinan Untuk Program Rehab Rumah Tidak Layak Huni Di Kabupaten Sidoarjo dapat disimpulkan bahwa indikator 
karakteristik fisik rumah yang berpengaruh terhadap status kemiskinan adalah status penguasaan, jenis atap terluas, kualitas atap, jenis dinding terluas, kualitas dinding, dan jenis lantai. Indikator yang berpengaruh paling dominan terhadap status kemiskinan yaitu jenis lantai.

\section{Saran}

Perlunya penggunaan data indikator kemiskinan yang tepat sebagai upaya mempercepat penanggulangan kemiskinan di Kabupaten Sidoarjo, khususnya rumah tidak layak huni. Pelaksanaan program pengentasan kemiskinan agar lebih tepat sasaran dan terukur sehingga bantuan yang diberikan dapat meningkatkan kesejahteraan dan mengurangi beban pengeluaran keluarga miskin.

\section{DAFTAR PUSTAKA}

Afandi, W.N. 2010. Identifikasi Karakteristik Rumah Tangga Miskin di Kabupaten Padang Pariaman (Studi Kasus Nagari Malai V Suku). Tesis: Universitas Andalas.

Direktorat Jenderal Pemberdayaan Masyarakat dan Desa, Kementerian Dalam Negeri. 2011, Pedoman Penyusunan Laporan Pelaksanaan Penanggulangan Kemiskinan Daerah (LP2KD), Jakarta.
Karya, D. 2013. Sinkronisasi Program Penanggulangan Kemiskinan di Kabupaten Indragiri Hilir Tahun 2012. Fakultas Ekonomi Universitas Islam Riau.

Notoatmojo. 2003. Prinsip-prinsip Dasar Ilmu Kesehatan Masyarakat. Jakarta: Rineka Putra.

Puteri, A.D. 2016. Penerapan Metode Regresi Ordinal untuk Menentukan Indikator Karakteristik Fisik Rumah Dominan terhadap Status Kemiskinan dalam Program Rehab Rumah Tidak Layak Huni di Kabupaten Sidoarjo. Skripsi: Fakultas Kesehatan Masyarakat Universitas Airlangga Surabaya.

Sudjana. 1996. Upaya Pelayanan Persepsi Kesadaran dan Penataan terhadap Masalah Lingkungan Hidup. Jakarta: Cides.

Suryahadi, A., Sumarto. 2001. Memahami Kemiskinan Kronis dan Kemiskinan Sementara di Indonesia.

Uyanto, S. 2006. Pedoman Analisis Data dengan SPSS. Yogyakarta: Graha Ilmu.

Tumangger. 2007. Studi Tentang Kondisi Fisik dan Lingkungan Rumah Penduduk di Desa Salak I Kecamatan Salak Kabupaten Pakpak Bharat. Skripsi. Medan: Jurusan Pendidikan Geografi. 